\title{
The use of valuations of healthcare services in other countries (basic henefits basket) in the tarififing process
}

\author{
Maria Świderek \\ Magdalena Fedoryszak-Rodź \\ Norbert Tyszka
}

Department of Tariffing, Agency for Health Technology Assessment and Tariff System

Address for correspondence: Maria Świderek, Wydział Taryfikacji, Agencja Oceny Technologii Medycznych i Taryfikacji, ul. Przeskok 2, 00-032 Warszawa, sekretariat@aotm.gov.pl

\section{Abstract}

The Agency for Health Technology Assessment and Tariff System is national institution supervised by Minister of Health. Agency is an advisory body in the reimbursement process. One of the Agency's roles is setting a tariff for publicly funded healthcare services. Determining the cost of medical services is one of the most important conditions for valuating these tariffs.

As in most European countries, the system of financing in-patient care in Poland is based on the Diagnosis Related Group system (DRG). DRG systems were created to increase efficiency in the use of available resources, and consequently to improve the quality of medical care. In order to compare the method and level of financing healthcare services with their equivalent abroad, the Agency analyzes information from other countries, especially those with GDP per capita similar to that of Poland. The Agency searches for patient group classification methods, payment methods, the shape of services and all factors affecting the valuation of services.

The article describes the Polish inpatient services system against the background of solutions functioning in the world. The pricing process was presented, with particular emphasis on the process of obtaining data on foreign tariffs and their impact on the construction and pricing of healthcare services in Poland.

Key words: medical service, costs, valuation, setting tariffs

Slowa kluczowe: świadczenia zdrowotne, koszty, wycena, taryfikacja

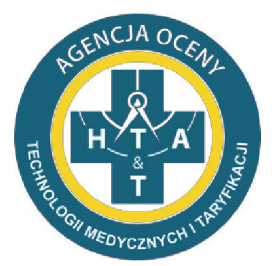

AGENCJA OCENY TECHNOLOGII MEDYCZNYCH I TARYFIKACJI

\section{Health services as the subject of valuation - basic concents}

The discussion of the issue of valuation of health services should begin with the notions of health services and the principles of their valuation. The current system of financing health services in Poland for inpatient treatment is based on the concept of Homogeneous Patient Groups (pol. Jednorodne Grupy Pacjentów, JGP), which is based on unit costs of patient treatment. The calculation of these costs requires valuation of various medical services provided to the patient.

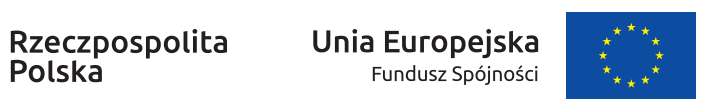

Health services are classified as socially desirable services and a particular type of public services, and their provision is, related to the implementation of the state's socio-economic policy among other things. They should be provided under certain conditions ensured by the state, which carries out regulatory and control activities for this purpose [1].

The basic type of health services are medical services provided by medical entities (hospitals, clinics, laboratories and others) to the recipient - the patient. A medical service consists of various strictly medical services, such as: medical examinations and advice, therapies, 
rehabilitation and nursing services, patient care; preventive, diagnostic and medical analyses, but also accompanying services, e.g. hotel, catering and information services. Each of them is equally important and affects the global value of the entire process of treating a patient suffering from a particular disease unit. In the practice of hospital treatment, these services may be relatively simple (e.g. performing laboratory tests), as well as very complicated (e.g. surgical procedures in a hospital). The more complicated the service is, the more difficult it is to evaluate it [1].

In the Act of 27 August 2004 on health care services financed from public funds ("Journal of Laws" of 2019, item 1373), medical services are health care services, the provision of which is the basic aim of the therapeutic activity of hospitals and other medical entities. They include health services, material health benefits and accompanying services [2].

Types of health services:

- guaranteed services - health care provision financed entirely or co-financed from public funds on the principles and within the scope specified in the Act;

- specialised services - provision of health care in all areas of medicine, except for basic health care;

- material health benefits - a service related to the treatment process, medicines, medical devices, including orthopaedic devices, and ancillary equipment;

- accompanying services - accommodation and boarding in a 24-hour or all-day health care facility and sanitary transport services;

- highly specialised services - health care services or medical procedures that meet all of the following criteria:

- the application for a benefit requires a high level of technical sophistication;

- the unit cost of benefits is high;

- health services - an action aimed at preventing, preserving, saving, restoring or improving health and other medical action resulting from the process of treatment or separate provisions regulating the principles of their provision [2].

At the same time, the Act clarifies the notion of hospital service as a 24-hour comprehensive health service consisting of diagnosis, treatment, care and rehabilitation, which cannot be provided under other inpatient and 24hour health services or outpatient health services. Hospital services also include in-patient services provided with the intention to terminate their provision within a period not exceeding twenty-four hours (Article 2.1.11) [2].

The specific features of the patient's treatment process which affect its value, include an individualised character closely related to the patient, and the difficulty of standardising. In the treatment process, there is a considerable diversity in the range of services provided and the way they are provided. It is worth adding that a patient usually benefits from many services at the same time, but the process of providing the same services may vary depending on the qualifications of the medical staff, the hospital's equipment and facilities, as well as the type of disease units and the patient's health condition, and its effects depend on the patient's cooperation with the doctor. It often happens that many functional units (e.g. wards, operating theatres, treatment rooms, laboratories) and even entities participate in the treatment process, and the package of services may be offered in different places and at different times. Moreover, the process of providing medical services takes place simultaneously with their consumption. For this reason, medical results cannot be stored [1].

In the health services market, medical services are provided at a specific price which, on the one hand, should be justified by the health needs of the patient and accepted by the payer and, on the other, should make it possible to obtain the necessary financial resources for the activities of the provider [1].

Among the methods of setting the prices of services, cost and market (demand) orientation is most often distinguished. In market terms, the value of a medical service is considered from the point of view of entities operating on the medical services market: health care providers (hospitals), payer (the NFZ, Polish National Health Service) and recipients of these services (patients), and in the general health insurance system, each of these entities has an impact on the selling price of a health care service [1].

The most-often used market-based pricing methods are the following:

- imitation method - the starting point for the calculation is the analysis of the prices of the competing entities operating on the market and setting their own proposal at a lower, equal or higher level in relation to them;

- demand-side methods - this approach is based on the assumption that the price should be set at the level that the customer expects. It consists in determining the customer's propensity to pay a certain price. The price of a service is therefore determined by the level of acceptance by the customer and not by the cost of providing the service [1].

In costing methods, the value of the services provided depends mainly on the patient's health condition and the treatment technology adopted. Costing methods are based on the assumption that the price should ensure coverage of all costs and enable a specific profit [1].

In order to apply costing methods in the process of setting the prices of medical services, awareness of the following is necessary:

- the actual costs of hospitals' operations and the costs of medical services they provide, the cost structure and their response to changes in the volume of services;

- the types and cost elements that should form the basis for pricing (e.g. fixed or variable costs, costs including invested capital, costs dependent on the entity or average costs of services provided on the market) [1]. Therefore, different categories of unit costs, such as full costs, technical manufacturing costs and unit variable costs may be used as the basis for determining the price of health services based on costing methodologies. The costing process plays a very important role in the cost-based pricing process [1]. 
Cost-based pricing methods are characterised by simplicity of calculations and easy access to cost information in the accounting system. In order to apply these methods, both traditional full cost calculation, variable cost calculation and other modern variants of cost calculation can be used. Their disadvantage is the omission of external factors having a significant impact on the price, such as demand, competitors' prices, financial capacity of the payer, or patients' preferences. In addition, it should be noted that cost-based pricing may not be covered by the payer's budget [1].

\section{Basket of basic services, for example hospital treatment}

Hospital treatment occupies a special position in all health care systems and is the largest consumer of health care funds both in Poland and in other countries [1].

The funding systems for inpatient care in most European countries are based on the Diagnosis Related Group (DRG) system. DRG systems aim to increase the transparency of services provided in hospitals and to increase efficiency in the use of available resources and consequently improve the quality of medical care. The main goal of the system is to classify patients into specific groups that are homogenous in terms of clinical appearance and used resources. Although each country has implemented its own unique DRG system, for the most part the base was the Health Care Financing Administration (HCFA), which was established in 1983 in the USA. Countries such as England, Austria and the Netherlands have developed their own DRG systems (Figure 1) [3].

Differences in patient classification systems (PCS) similar to the DRG model, in individual countries translate into differences in the definition of patient groups or hospital products. In addition, the uniqueness of systems creates difficulties in comparing hospital performance or funding levels in different countries [4].

In DRG systems derived from HCFA-DRG, individual homogeneous groups of patients are divided according to basic diagnostic categories (Major Diagnostic Category, MDC) and in the case of Polish and English systems, the groups are divided into chapters (pol. rozdziaty) and further into sections (pol. sekcje). Chapters or basic diagnostic categories refer to individual internal organs, body parts or disease units. The sections refer to the type of treatment used - surgical or non-invasive [4].

There is a different number of groups in different systems. The Polish system of Homogeneous Patient Groups (pol. Jednorodne Grupy Pacjentów, JGP) has the smallest number of groups -677 , while the Dutch Diagnose Behandeling Combinaties (DBC) has 4,400. The number of basic diagnostic categories also ranges from 19 (JGP) to 29 (Groupes Homogènes des Malades, GHM). Table I presents the characteristics of selected patient classification systems, i.e: All Patient Refined DRG (APR-DRG), Australian Refined DRG (AR-DRG), German DRG (G-DRG), GHM, Nord-DRG, Healthcare Resource Group (HRG), Leistungsorientierte Krankenanstaltenfi nanzierung (LKF), (DBC).

\section{Procedures and diannosis classification systems}

When classifying patients into a specific DRG group coding systems for clinical diagnoses and medical procedures are used. The International Statistical Classification of Diseases and Related Health Problems (ICD-10) and the International Classification of Procedures in Medicine (ICD-9) are used for coding diagnoses. Almost all countries use modified ICD-10 codes tailored to their needs. Most often a fifth digit is added to the general layout of the ICD-10 codes to allow for a more detailed description of the conditions [4].

\begin{tabular}{|l|c|c|c|c|c|c|c|c|c|}
\hline & APR-DRG & AR-DRG & G-DRG & GHM & Nord-DRG & HRG & JGP & LKF & DBC \\
\hline Groups & 1306 & 803 & 1318 & 2199 & 798 & 2313 & 677 & 1513 & 4400 \\
\hline $\begin{array}{l}\text { Categories } \\
\text { MDC/Chapters }\end{array}$ & 25 & 24 & 26 & 29 & 25 & 21 & 19 & - & - \\
\hline Sections & 2 & 3 & 3 & 4 & 2 & 2 & 2 & 2 & - \\
\hline
\end{tabular}

Table I. Characteristics of patient classification systems

Source: Own elaboration based on: Kobel C. et al., Systemy DRG i zbliżone systemy kwalifikacji pacjentów w Europie, in: Busse R. et al., Jednorodne grupy pacjentów w Europie. W stronę przejrzystości, efektywności i jakości w szpitalach, Narodowy Fundusz Zdrowia - Centrala, Warszawa 2013: 55-79 [4]; https://www.3m.com/3M/en_US/health-information-systems-us/ providers/grouping-and-classification/apr-drgs/ (accessed: 18.07.2019) [5]; https://www.ihpa.gov.au/publications/development-australian-refined-diagnosis-related-groups-ar-drg-v90 (accessed: 18.07.2019); https://www.ihpa.gov.au/publications/ development-australian-refined-diagnosis-related-groups-ar-drg-v90 (accessed: 18.07.2019) [6]; https://app.reimbursement.info/ drgs? years $=2019 \& m d c s=24$ (accessed: 18.07.2019) [7]; https://app.reimbursement.info/drgs? years $=2019 \& m d c s=24$ (accessed: 18.07.2019) [8]; http://www.norddrg.net/norddrgmanual/NordDRG_2012_NC/index.htm (accessed: 18.07.2019) [9]; https://improvement.nhs.uk/resources/national-tariffl (accessed: 18.07.2019) [10]; Zarzadzenie $\mathrm{nr}$ 77/2019/DSOZ Prezesa Narodowego Funduszu Zdrowia z dnia 27 czerwca 2019 roku zmieniające zarządzenie w sprawie określenia warunków zawierania i realizacji umów w rodzaju leczenie szpitalne oraz leczenie szpitalne - świadczenia wysokospecjalistyczne [11]; https://www.sozialministerium.at/site/Gesundheit/Gesundheitssystem/Krankenanstalten/LKF_Modell_2019/Kataloge_2019 (accessed: 18.07.2019) [12]; https://www.hspm.org/countries/netherlands25062012/livinghit.aspx?Section=3.7\%20Payment\%20mechanisms\&Type=Section (accessed: 18.07.2019) [13]. 


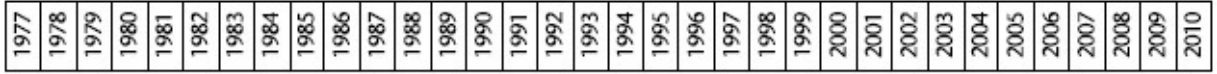
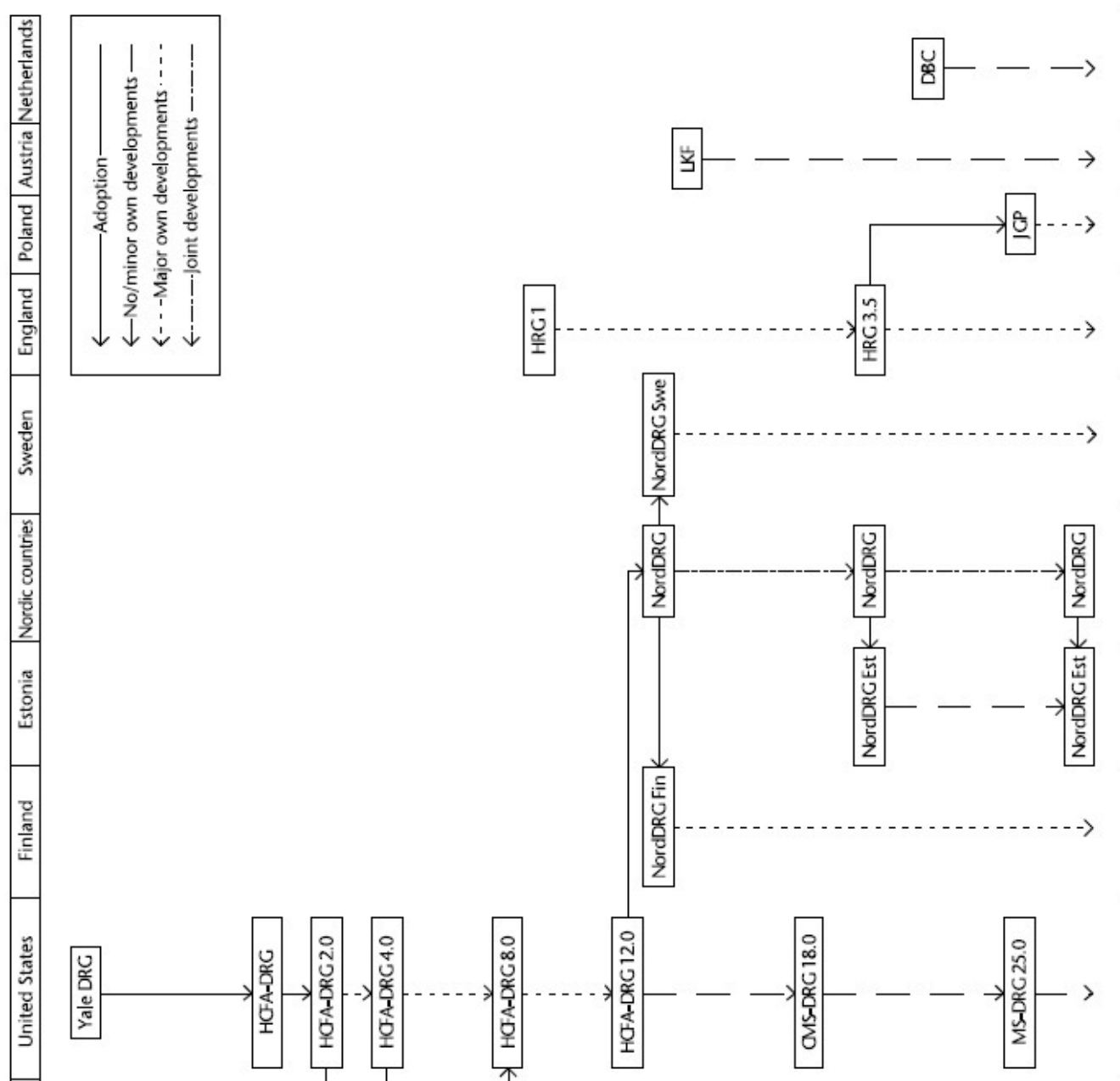

屁

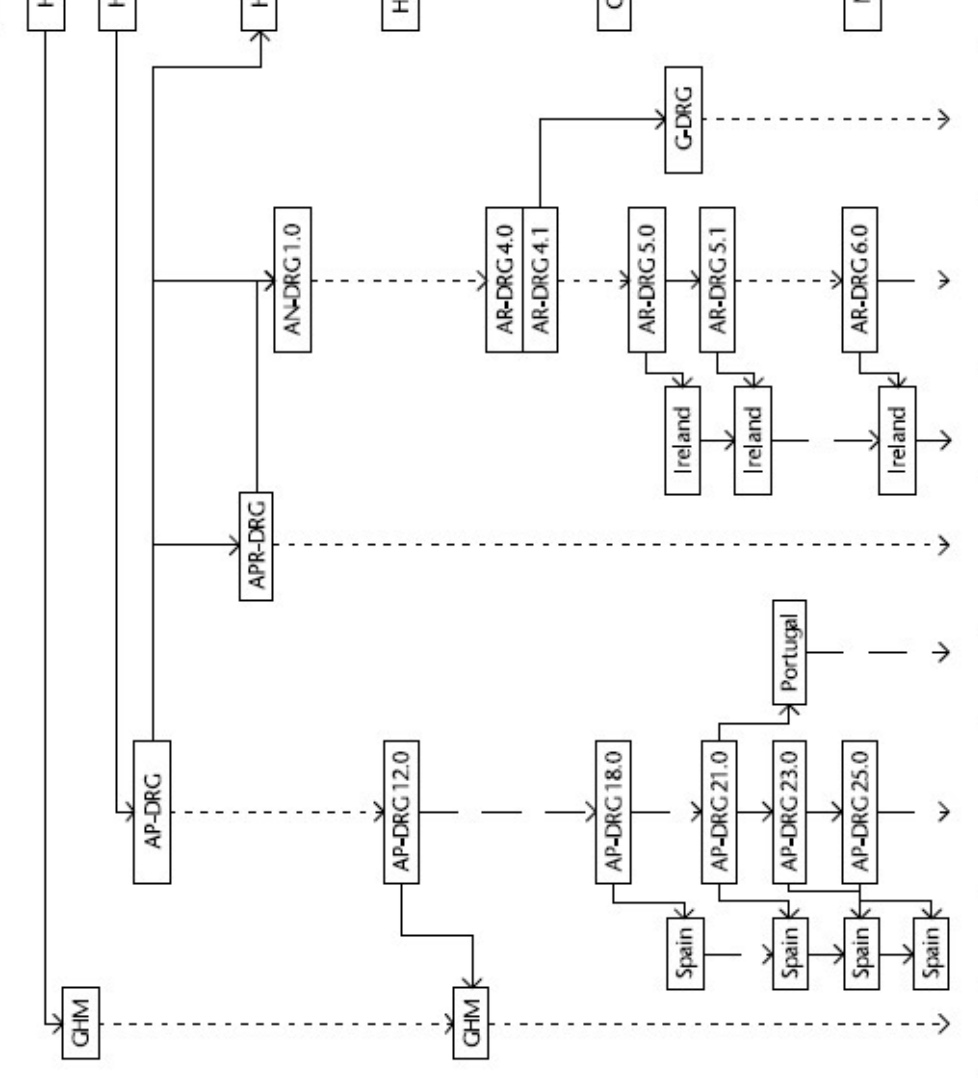

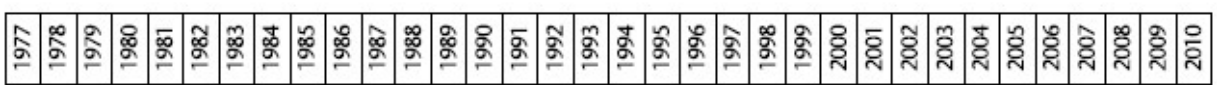

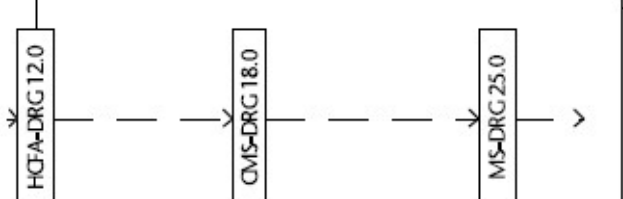

ن है

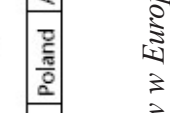

.

¿

हे

ริ

รัँ

ร

वं

รั)

$-1$

$\frac{\sqrt{\frac{5}{n}}}{5}$

है

这

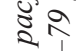

:ละ

s

בิ

로․

के

$\cong$

ㄱำ

(1)

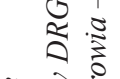

紊密

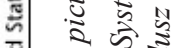

₹ี

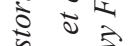

$1 \frac{\pi}{2}$

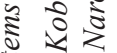

के

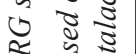

0 然

$\stackrel{0}{3}$

各

$\approx \approx$

จิ

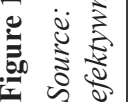




\begin{tabular}{|l|l|l|}
\hline \multicolumn{1}{|c|}{ Country } & \multicolumn{1}{|c|}{$\begin{array}{c}\text { Coding of } \\
\text { diagnoses }\end{array}$} & \multicolumn{1}{|c|}{$\begin{array}{c}\text { Coding of Medical } \\
\text { Procedures }\end{array}$} \\
\hline Austria & ICD-10-BMSG-2001 & Leistungskatalog \\
\hline England & ICD-10 & OPCS \\
\hline Estonia & ICD-10 & $\begin{array}{l}\text { NCSP (Nomesco Classifica- } \\
\text { tion of Surgical Procedures) }\end{array}$ \\
\hline Finland & ICD-10-FI & NCSP-FI \\
\hline France & CIM-10 & CCAM \\
\hline Germany & ICD-10-GM & OPS \\
\hline Ireland & ICD-10-AM & ACHI \\
\hline TheNetherlands & ICD-10 & $\begin{array}{l}\text { Elektronische DBC } \\
\text { Typeringslijst }\end{array}$ \\
\hline Poland & ICD-10 & ICD-9-CM \\
\hline Portugal & ICD-9-CM & ICD-9-CM \\
\hline Spain & ICD-9-CM & ICD-9-CM \\
\hline Sweden & ICD-10-SE & $\begin{array}{l}\text { KVÅ (Klassifikation av } \\
\text { vårdåtgärder - Swedish } \\
\text { version of NCSP) }\end{array}$ \\
\hline NordDRG & ICD-10 & NCSP \\
\hline
\end{tabular}

Table II. Coding of medical diagnoses and procedures

Source: Own elaboration based on Kobel C. et al., Systemy DRG i zbliżone systemy kwalifikacji pacjentów w Europie, in: Busse R. et al., Jednorodne grupy pacjentów w Europie. W strone przejrzystości, efektywności i jakości w szpitalach, Narodowy Fundusz Zdrowia - Centrala, Warszawa 2013: 55-79 [4].
The coding of medical procedures varies greatly from country to country. Most countries have developed a separate procedure coding system, ranging from the Australian Classification of Health Interventions (ACHI) to the Classification Commune des Actes Médicaux (CCAM, Leistungskatalog). The discrepancies also concern the number of procedures. The LKF system contains 1,500 items, while the German system of procedure classification codes (Operationen- und Prozedurenschlüssel, OPS) contains 30,000 items (4). Detailed information on the classification of medical procedures and diagnoses used in each country is provided in Table II.

All DRG systems used in Europe use the data regarding patient hospitalisation. Clinical data (medical diagnoses, procedures) derived from the discharge are classification variables in all systems. By contrast, a demographic and administrative variable, such as the patient's gender, is only used in the NordDRG system. Few systems also use variables expressing the level of resource use [4].

There are also differences in the number of severity levels of the patient's condition. Most countries have a limited number of severity levels. Their number ranges from two (NordDRG), through five (GHM), to an unlimited number (G-DRG and LKF). In G-DRG and LKF

\begin{tabular}{|c|c|c|c|c|c|c|c|c|c|}
\hline Systems & AP-DRG & AR-DRG & G-DRG & GHM & Nord-DRG & HRG & JGP & LKF & DBC \\
\hline \multicolumn{10}{|l|}{$\begin{array}{l}\text { Classification variables } \\
\text { Clinical variables }\end{array}$} \\
\hline Diagnoses & $\mathrm{X}$ & $\mathrm{X}$ & $\mathrm{X}$ & $\mathrm{X}$ & $\mathrm{X}$ & $\mathrm{X}$ & $\mathrm{X}$ & $\mathrm{X}$ & $\mathrm{X}$ \\
\hline Procedures & $\mathrm{X}$ & $\mathrm{X}$ & $\mathrm{X}$ & $\mathrm{X}$ & $\mathrm{X}$ & $\mathrm{X}$ & $\mathrm{X}$ & $\mathrm{X}$ & $\mathrm{X}$ \\
\hline Neoplasm/ malignancy of neoplasm & $\mathrm{X}$ & $\mathrm{X}$ & $\mathrm{X}$ & - & - & - & - & - & - \\
\hline Type of care & - & - & - & - & - & - & - & - & $\mathrm{X}$ \\
\hline \multicolumn{10}{|l|}{ Administrative/Demographic variables } \\
\hline Hospital administration procedure & - & - & - & - & - & $\mathrm{X}$ & $\mathrm{X}$ & - & - \\
\hline Age & $\mathrm{X}$ & $\mathrm{X}$ & $\mathrm{X}$ & $\mathrm{X}$ & $\mathrm{X}$ & $\mathrm{X}$ & $\mathrm{X}$ & $\mathrm{X}$ & - \\
\hline Weight at birth (neonates) & $\mathrm{X}$ & $\mathrm{X}$ & $\mathrm{X}$ & $\mathrm{X}$ & - & - & - & - & - \\
\hline Hospital discharge procedure & $\mathrm{X}$ & $\mathrm{X}$ & $\mathrm{X}$ & $\mathrm{X}$ & $\mathrm{X}$ & $\mathrm{X}$ & $\mathrm{X}$ & - & - \\
\hline Sex & - & - & - & - & $\mathrm{X}$ & - & - & - & - \\
\hline Mental health legal status & - & $\mathrm{X}$ & $\mathrm{X}$ & - & - & - & - & - & - \\
\hline \multicolumn{10}{|c|}{ Variables concerning the level of resource use } \\
\hline $\begin{array}{l}\text { Lenght of stay/treatment status on } \\
\text { a one-day basis }\end{array}$ & - & $\mathrm{X}$ & $\mathrm{X}$ & $\mathrm{X}$ & $\mathrm{X}$ & $\mathrm{X}$ & $\mathrm{X}$ & - & - \\
\hline Respiratory support & - & - & $\mathrm{X}$ & - & - & - & - & - & - \\
\hline Treatment conditions/settings & - & - & - & $\mathrm{X}$ & - & - & - & - & $\mathrm{X}$ \\
\hline Stay on the special ward & - & - & - & - & - & - & - & $\mathrm{X}$ & - \\
\hline Medical specialty & - & - & - & - & - & - & - & - & $\mathrm{X}$ \\
\hline Care requirements & - & - & - & - & - & - & - & - & $\mathrm{X}$ \\
\hline & & & & & & & & & \\
\hline Level of severity/state/complexity & 3 & 4 & No limit & 5 & 2 & 3 & 3 & No limit & - \\
\hline $\begin{array}{l}\text { Aggregate indicator of the complex- } \\
\text { ity of the case }\end{array}$ & - & PCC & PCC & $\mathrm{X}$ & - & - & - & - & - \\
\hline
\end{tabular}

Table III. Classification variables and severity levels of patient condition in global patient classification systems (PCS) similar to the DRG model

Source: Own elaboration based on Kobel C. et al., Systemy DRG i zbliżone systemy kwalifikacji pacjentów w Europie, in: Busse R. et al., Jednorodne grupy pacjentów w Europie. W stronę przejrzystości, efektywności i jakości w szpitalach, Narodowy Fundusz Zdrowia-Centrala, Warszawa 2013: 55-79 [4]. 
systems, base groups are divided into a number of target groups that will ensure a relatively homogeneous level of resource use in each of them. In addition to DBC and LKF systems, in other countries, the severity of a patient's condition or the complexity of the condition is determined mainly by secondary diagnoses (co-morbidities and complications - CC). In the classification into the appropriate group in AR-DRG and G-DRG systems, all secondary diagnoses through a cumulative index (Patient Clinical Complexity Level, PCCL) are used. Other DRG systems (besides DBC) use the highest ranked secondary diagnoses (4). Detailed information on classification variables in individual DRG systems is presented in Table III.

Work is ongoing in individual countries to ensure that the DRG system covers not only hospital but also psychiatric and rehabilitation treatment. The creation of a system for classifying patients undergoing rehabilitation is associated with limitations such as: heterogeneous duration of rehabilitation, degree of resource use and lack of superior procedures. However, in Germany, USA, France, or Switzerland there are grouping systems of rehabilitation treatment. These systems take into account the rates of loss of performance, coexisting conditions and age (Germany, USA) or the number of days, weeks of rehabilitation (France, Switzerland) [4].

\section{DRG system in Poland}

The DRG system in Poland was implemented in 2008 as Homogeneous Patient Groups (JGP). It was based on the British patient classification system Healthcare Resource Groups 3.5, which was adapted to Polish conditions. The system is divided into 19 sections, referring to the anatomical or physiological system of the body, or a specific clinical specialization. The sections contain a total of 677 of Homogenous Patient Groups, characterized by diagnoses and/or procedures. The groups are then divided into surgical and non-invasive units. A distinction is made between 410 surgical and 267 non-invasive groups. The classification of patients into the appropriate homogenous patient group is based on information from the hospital discharge. The following data are used: medical diagnoses (ICD-10), performed medical procedures (ICD-9-PL), complications and coexisting diseases, age, type of hospitalization, type of discharge and length of stay [4, 14].

\section{Valuation of health services in selected countries}

The process of valuing health services will vary from country to country due to its diversity at the level of financing methods, the way patients are classified, as well as the type of medical technology used. Below are the rules for setting tariffs in selected countries.

\section{England}

In England, since 2016, the institution responsible for setting the NHS tariff is the independent NHS Improvement. In addition, it is responsible for managing the Reference Costs database, publishing guidelines for the calculation of reference costs, data collection templates, and calculating the so-called Reference Cost Index. Almost all hospital care is financed by the prospective Payment by Results (PbR) system. The analysis of hospital costs of patients is based on the HGR4+ classification system [15].

The process of setting price tariffs takes several years. The first step is to collect data, then in the following year they are analysed, and only in the third year are price tariffs set on their basis. Valuation of medical services is possible after the coding of the patient's treatment process and grouping of data in the national database Secondary Uses Service (SUS) [15].

All providers prepare information on average reference costs on an annual basis and submit it to the database via a special IT system. Hospitals have access to cost data at the level of HRG and other cost facilities from all hospital trusts. The average reference costs obtained, including labour, equipment and investment costs, form the basis for setting price tariffs. The data analysis does not include costs of those services which are not financed in the HRG system and the costs of so-called outliers, i.e. those cases whose costs are less than one twentieth of the national average cost of treatment in a given group or twenty times higher than this average [15].

The price of a given diagnostic group is calculated based on the following formula:

$$
T_{i}=\delta_{i}\left[p_{i} C_{i}+\left(1-p_{i}\right) D_{i}\right]
$$

where:

$T_{i}$ - the tariff price for $\mathrm{HRG}_{\mathrm{i}}$;

$C_{i}$ - average reference costs of treatment for inpatient $\mathrm{HRG}_{\mathrm{i}}$ patients;

$D_{i}$ - average reference costs of treatment of $\mathrm{HRG}_{\mathrm{i}}$ patients on a dayto-day basis;

$p_{i}$ - the proportion of cases in a given HRGi group treated inpatiently;

$\delta_{i}$ - inflation rate for $\mathrm{HRG}_{\mathrm{i}}[15]$.

Due to the delay between the time when costs are incurred and the price of health services, the costs of each HRG group are adjusted for inflation. The established price tariff is then adjusted by the market forces factor (MFF). The MFF aims to compensate for differences in labour costs, or land and building prices in a given area. This is due to the fact that the average costs of hospitals largely depend on their geographical location [15].

The final valuation of health services is also affected by changes in clinical standards and medical technologies issued by NICE (National Institute for Clinical Excellence). The tariff increase is possible due to the need to use more modern and more expensive medical technologies, which increase costs in hospitals. Price adjustments are also made for in the case of long and short stays, expensive medicines, specialist care and best medical practices which have been developed and priced to support high quality care [15]. 


\section{France}

In France, the valuation of health services is the responsibility of an independent body: the Agence technique de l'information sur l'hospitalisation (ATIH). Hospital financing is based on the GHM classification system [15].

The Technical Hospital Information Agency collects medical information and detailed cost reports on patients' hospitalisation from an annually selected group of hospitals, which have different legal status (public, private, clinical, oncology centres), and represent different regions of France. These hospitals are required to calculate costs based on a standardised costing model. Hospitals receive additional funding for their participation in the study [15].

Medical and cost data are collected and processed within the National Cost Analysis System (ENCC). On the basis of the cost data collected in this way, ATIH determines and publishes information about the average reference costs, i.e. the average costs for each GHM group, every year. The information on treatment costs is then used to establish national cost weights, which are expressed in points and are updated annually. The point weights shall then form the basis for setting the prices on which hospitals are billed to the payer. The cost weights are determined using statistical and econometric methods. The prices of health services are determined on the basis of cost data collected from healthcare providers two years earlier [15].

Average costs per GHM group are calculated separately for public and private hospitals. GHM prices in private and public hospitals are based on different cost categories. The pricing of medical services in public hospitals includes all cost categories (salaries of medical staff, investments in technical equipment, materials, devices, medicines), whereas in private hospitals the doctors' labour costs and part of the hospital infrastructure costs are not included as they are accounted for under a different system [15].

When establishing the average reference costs, excluded are those costs which are not financed at all on the basis of the GHM category, e.g. amounts for training and research, costs for expensive medicines and medical devices, costs for dialysis and radiotherapy. In addition, so-called extreme cases on the basis of length of stay and treatment costs, i.e. cases exceeding 2.5 times the patient's average hospital stay and cases for which too high or too low a cost was incurred, are removed from each GHM group. The coding of diagnostic categories is also verified [15].

Due to the small group of hospitals providing annual cost data, average GHM costs are weighted by type of hospital, with five types of hospitals being distinguished for the public sector (large general hospitals treating more than 16,000 cases per year, smaller general hospitals treating less than 16,000 cases per year, oncology centres, clinical hospitals and private non-commercial hospitals). On the other hand, to determine the weighting index of average GHM costs, the following information is taken into account: average length of patient's stay in hospital, average length of patient's stay in the emergency department, and average number of medical procedures performed by particular types of hospitals [15].

Average reference costs provided by healthcare providers are the basis for setting price tariffs. However, these tariffs are subject to significant modifications. Prices are ultimately decided by the Ministry of Health, also taking into account the budgetary resources for the hospital sector and other public health priorities which are the responsibility of national health policy. Indeed, the priorities set are intended to promote certain activities and encourage hospitals to provide certain health services [15].

\section{Germany}

In Germany, the Institut für das Entgeltsystem im Krankenhaus (InEK) is responsible for the evaluation of individual diagnostic groups. The G-DRG system (15) is used to finance hospital care.

Each G-DRG case has a fixed cost weighting, which is calculated by InEK on the basis of the average costs obtained from the hospital group. All hospitals provide structural data (e.g. type of hospital, form of ownership, number of beds, number of doctors, total costs) and data needed to group patients into individual G-DRGs. In order to evaluate individual diagnostic groups, a specific group of hospitals has been obliged to group cost data in detail and record them at the patient level. Other hospitals may voluntarily submit cost data to the central database. InEK has also developed a standard cost accounting system (Kalkulationshandbuch), which must be used by hospitals that provide cost data [15].

Clinical and cost data are sent to the Data Centre before being submitted to InEK, where they are checked for, among other things, formal and technical errors as well as for financial and medical reasons. The verified data is used by InEK to prepare a catalogue of fees, which will be valid in the following year [15].

During the analysis of the data, extreme cases (outlier), which do not fall within the set standards for the length of patient's stay in hospital, are eliminated. These standards are determined by the arithmetic mean of the length of stay and the standard deviation of the length of stay. The average cost of the remaining cases (inlier) of a given G-DRG is divided by a reference value (the arithmetic mean of all typical cases), which is determined for a given year. The cost weights calculated in this way make it possible to define the relationship between the different categories of G-DRG in terms of resource use. The cost weights are updated annually by InEK [15].

The value of the tariff for individual G-DRG groups is determined by multiplying the cost weight assigned to the group by the so-called base rate, which is the price set for the reference G-DRG group, i.e. the one to which a weight index equal to one has been assigned [15].

In Germany, the hospital charge catalogue contains G-DRG categories with assigned cost weights and those G-DRG categories which do not have assigned cost weights, and also contains additional charges. 
G-DRG rates which are not assigned cost weights due to insufficient data for calculating cost weights or because of too great a variation in the cost of cases are subject to the process of negotiation between individual health insurance companies and hospitals. Unlike in other countries, G-DRG tariffs do not include investment costs [15].

However, additional fees allow for financing longterm hospital stays, expensive procedures and very expensive medicines. Most of these fees are set at national level, while some are negotiated with hospitals. Under the German system of service financing, hospitals may negotiate additional reimbursement 'per case' or 'per person per day of stay' for highly specialised medical services if the hospital demonstrates that the service cannot be adequately reimbursed on the basis of G-DRG and additional charges [15].

\section{The henefit valuation process in Poland}

Since 2015, the valuation of health care services in Poland has been handled by the Agency for Health Technology Assessment and Tariff System (pol. AOTMiT). According to the AOTMiT tariff methodology for health care benefits, the primary purpose of the valuation is to establish a tariff/price for health care services financed from public funds. This is possible under the assumption that the purpose of the tariff is to balance the supply of health services and health needs, to ensure the best availability of guaranteed services, and to be economical in spending public funds [16].

The tariffing process is based on the actual costs incurred in the provision of these benefits and on the interrelationship of cost levels between the individual benefits [16].

\section{Assumptions of the tariffing process in AOTMiT}

The basic method of determining benefit tariffs is cost analysis, where the main source of information is financial and non-financial data on guaranteed benefits, collected and reported by providers. This analysis may be supplemented by an analysis of the demand and supply of benefits, as well as other factors influencing the development of the health services market. In justified cases, the AOTMiT allows the detailed data analysis to be replaced by:

- information about the type and size of resources involved, typical of the process of implementation of a given service, coming from providers or experts (the so-called 'expert milestones');

- analyses of commercial prices of services at home and abroad [16].

The AOTMiT allows for this departure from norm when:

- the time limit for the tariffing is short, e.g. in a situation where the results of the analysis of waiting lists in terms of the number of people on the waiting lists and the waiting time for the benefit indicate the need to introduce changes quickly;
- the subject of the analysis is a new service or new medical technology for which there are no real data on the costs incurred, the subject of the analysis is a relatively inexpensive service that is generally implemented, also commercially, or it is supported by expert advice [16].

\section{Methods of determining benefit tariffs}

The basic methods for setting tariffs are:

- cost analysis based on data from providers (including expert milestones), analysis of market data, including primarily prices of commercially performed services;

- foreign prices analysis [16].

The total cost of healthcare provision is made up of two main types of costs incurred by healthcare providers:

- fixed costs - primarily human resources costs and the costs of purchasing, replacing and maintaining the provider's equipment and premises, as well as all costs related to the functioning of the entity (collectively referred to as infrastructure costs). The data on fixed costs are analysed together with non-financial data on groups of human resources, the amount of those resources and infrastructure involved in the service;

- variable costs - mainly costs of medicines and medical devices, as well as medical procedures. The cost data are supplemented by data on the type and volume of consumption of medicines and medical devices and the type of procedures performed under the benefit [16].

\section{Analysis of financial and accounting data}

The financial and accounting data serve primarily to calculate the following elements of the total cost of benefits:

- personnel costs - salaries of particular professional groups taking part in the procedure and to calculate the cost of a person-day stay in a ward in case of stationary benefits, costs of staff involvement in providing non-stationary benefits;

- infrastructure costs - which consist of costs of premises and equipment and apparatus; these data are used to calculate: the cost of a person-day stay at a ward in the case of stationary benefits, costs of fixed nonstationary benefits, costs of procedures, including surgical procedures [16].

\section{Analysis of details of individual health services}

Details of individual benefits provided are used to determine variable costs comprising the following components:

- type, quantity and price of individual medicines and medical devices used in a given service;

- type and average number of individual medical procedures carried out in a given service, their duration, the staff involved and the costs of these procedures;

- length of patients' stay in individual hospital wards, used to estimate the costs of hospitalisation [16]. 


\section{Sensitivity analysis}

The analysis of medical and cost data coming from many providers and concerning many patients or cost centres requires averaging of values that may be very scattered, making certain assumptions, and making corrections or additions to the information. Such a procedure may result in uncertain estimates [16].

In order to examine the impact of uncertain parameters on the outcome of the cost benefit analysis, the AOTMiT may conduct a single- or multi-directional sensitivity analysis. The sensitivity analysis will concern those parameters which are associated with the highest uncertainty, as well as those which have a significant impact on the outcome of the cost analysis. The examined parameters, depending on the specificity of the benefit, may include: length of hospitalization, duration of the procedure, duration of the benefit, staff involvement, frequency of procedures/medicines/medical devices, unit costs of highcost procedures/medicines/medical devices, staff remuneration rates, depreciation costs, and other [16].

\section{Establishing the benefit cost}

The total cost of health care provision is the sum of the following elements:

- the cost of the stay, which is the product of the average hospital stay and the average cost of a man-day in the case of in-patient services or the cost of infrastructure and salaries in the case of other services;

- the average total cost of medicines, medical devices and procedures;

- in specific situations, the costs of the primary benefit provision are taken into account;

- the residual value is increased by the multiplier of changes in the amount of benefit costs [16].

Where, despite the best endeavours, it has not been possible to obtain from providers the data necessary to establish the tariff, the draft tariffs may be estimated on the basis of other sources, such as commercial prices or valuations of similar benefits in other countries [16].

\section{Costs of the basic benefit security}

In the case of life-saving benefits provided as an emergency service, which involves the need to maintain readiness in centres carrying out medical procedures, the costs of basic benefit security resulting from the need to maintain on-call duty in the operating theatre and other treatment rooms are added to the tariff [16].

\section{Multiplier of changes in the amount of benefit costs}

In order to take into account changes in the operating costs of healthcare entities over time in the tariff, as well as to determine the cost of capital necessary to ensure current and future demand of entities for infrastructure and services, a multiplier of cost changes is calculated. This multiplier has a twofold role: update of the tariff at the date of issue and a one-year development bonus [16].

\section{Analysis of commercial and foreign price lists}

For services which are also commonly provided outside the public health insurance system (i.e. financed from resources other than public funds), it is possible to establish a price on the basis of commercial price lists [16].

As the prices in the commercial price lists are increased by the provider's profit margin, the tariff for the publicly financed service is set at the level of the 10th percentile of the price list under consideration. Such an analysis can be made when the sample under examination is large and uniform. Since the commercial price lists under analysis determine the costs of the current period and not of previous periods, the tariff calculated in this way is increased by a part of the multiplication factor for the one-year development premium to take account of projected future changes in cost levels [16].

Where it has been impossible or there has been a failed attempt to obtain the data necessary to establish the benefit tariff from providers or market data from the Polish market, foreign valuations may form the basis for establishing the proposed benefit tariff. In accordance with the AOTMiT methodology, price determination in such a case includes the following steps:

1. Establishing the following relationship in foreign systems:

$\mathrm{A}=$ the price of the tariffed benefit/ arithmetic mean of the prices of benefits from the basic basket;

$\mathrm{B}=$ current average price of benefits for the above mentioned basic basket in Poland.

2. Calculation of the proposed new price of the tariffed benefit as: A x B [16].

\section{Setting the tariff}

Analyses carried out in accordance with the criteria described above and the draft tariffs drawn up on the basis of these criteria are the starting point for public consultation and the collection of possible comments from interested parties [16].

In the final stage, the draft tariffs are discussed by the Tariff Council, whose tasks include proposing directions for tariff changes and giving its opinion on the tariffs [16].

Not only the results of the cost analysis are considered, but also the comments made during the consultations, information about the demand for services and the available potential for their implementation, the objectives of the state's health policy, the activities of other stakeholders in the health system, etc. The Council may commission additional analyses and calculations and modify tariffs based on the aforementioned aspects [16].

\section{Analysis of prices of foreign henefits in the tariffing process}

In accordance with the AOTMiT service tariff methodology, in the case of services for which equivalents in health care systems operating in other countries can be 
indicated, foreign prices can also be a reference point for determining the price of a service in Poland. By searching the available information resources, mainly the websites of foreign institutions dealing with health technology assessment and benefit tariffing, the Agency obtains data on benefits from those countries in which the benefits are distinguished in a similar way as in Poland. In particular, the health care systems of EU countries and countries with a similar GDP to Poland are analysed.

While absolute values of foreign tariffs cannot be taken directly as reference values, due to differences in purchasing power parity and the amount of funds allocated to health care, in many cases it is possible to use other data on the construction of the analysed tariffs. Among other things, the following are taken into account: information on the system for the settlement of benefits, the rules for the construction of the settlement elements, the relationship between identical or similar benefits, including the relationship between their value, and any additional elements which may help to establish the final weighting of tariffs in a given system and among other settlement systems.

Each analysis shall also include Purchasing Power Parities (PPP) information. The PPP indicator is used to convert currencies in such a way as to eliminate price level differences between countries and to determine the actual purchasing power of a currency. PPPs are weighted average price ratios established for OECD countries. In the OECD database, these price relations are transformed in such a way that they express the purchasing power of each country, i.e. that a given sum of money in US dollars, when converted into different currencies in units of purchasing power parity, forms the same basket of goods and services. PPP differs from the exchange rate and can be higher or lower.

In the literature on the subject, Purchasing Power Parity (PPP) can be defined by means of several indicators. For comparison purposes, the Comparative Price Levels (CPL) are used in analyses. This indicator expresses the purchasing power of a country in relation to the average for OECD countries $(\mathrm{OECD}=100)$.

Costs and prices in other currencies, used in the process of determining the benefit tariff, are converted into PLN according to the current exchange rates published on the website of the National Bank of Poland. The source of data concerning PPP and CPL are the statements published by the OECD (balance at the end of the previous year is most often quoted).

\section{Limitations on applications}

Unfortunately, it should be noted that applying on the basis of the foreign tariffs found is linked with a few quite serious limitations. Besides the influence of economic factors discussed above, the first and most important limitation is the fact that national systems of patient groups are constructed differently from the Polish system of JGP. Over the years, despite a common starting point, they have undergone numerous transformations, which makes comparative analyses difficult. Despite many similarities in structure and the fact that the algorithm of construction of settlement products is known, it is often impossible to compare specific groups or even single benefits. The task is also hindered by the fact that the costs included in the tariff and their structure are not fully identified, even in the case of almost identically constructed billing products. In addition, it should be borne in mind that the systems of patient groups are based on various medical classifications, often transformed for the purposes of specific national reporting systems, and the method of settlement, resulting from the diversity of insurance systems and legal solutions, can also significantly influence the final tariff.

Another constraint, often unconscious, are population differences - epidemiological, behavioural (e.g. occurrence of certain cancers, pathological obesity) between countries. They may affect the clinic and the therapeutic methods used, and have a significant impact on the design of services, which also prevents their direct comparison. This aspect is directly linked to the impact of national health policies on tariffs. The tariff is sometimes a tool used to control the provision of services. It may be artificially inflated or understated in order to achieve a specific effect, e.g. application of a specific therapeutic method or redirection of the stream of patients from hospital treatment to outpatient treatment. Lack of knowledge about this aspect may also lead to wrong conclusions.

Of course, there are many more factors that may hinder comparison (e.g. historical circumstances, co-payment, funding of providers, additional clinical factors), but their impact is not as significant as those described above, and their detailed description exceeds the framework of this study.

\section{Using foreign valuations for cost analysis - selected examples}

Foreign tariffs are a fixed component of tariff analyses and, as mentioned earlier, despite the existing limitations, they are an important reference point for the shape of tariffs for settlement products and for determining the cost relationships between them. In order to reflect the impact of foreign valuations on Polish tariffs, three examples have been selected that will allow tracing the different mechanisms in the process of establishing benefit tariffs.

The following benefits were presented as examples of using foreign valuations for cost analysis:

1. Comprehensive pancreatic treatments - the effect of the time of stay on the applied cut-offs and the resultant tariff related to the time of hospitalization.

2. Hip endoprosthesis - construction of the benefit and the influence of expensive medical devices on the tariff value.

3. Guaranteed benefits covering the treatment of diseases of the nervous system by means of implantable electrical stimulation devices - the design of the benefit and, in particular, ways of taking into account high-cost medical devices. 
4. Residence benefits - valuation of the costs of mandays for hospitalisation related to the treatment of cancer.

It should be borne in mind that the tariff values and rules for the settlement of benefits in the countries concerned indicated below, were presented on the date of publication of the relevant tariff reports. The current tariff rules and values may have changed and may differ from those presented in the statement. Additionally, for the sake of transparency, tables with macroeconomic indicators for individual countries were omitted. All information is available in the relevant tariff reports published in the 'BIP' of the Agency.

\section{Guaranteed benefits including comprehensive pancreatic treatments (JGP G31)}

The only radical treatment for pancreatic malignant tumors is to remove the tumor during surgery. Depending on the location of the tumor, the following are removed: the head of the pancreas (Whipple procedure or its modifications), the tail of the pancreas (distal pancreatectomy) or the entire pancreas (sometimes in pancreatic body tumours). Depending on the type of operation, in addition to the resection of part of the pancreas, the gallbladder, bile ducts, duodenum, spleen, and part of the stomach are removed. Pancreatic surgeries are serious procedures with a significant percentage of complications (most often resulting from leakage from various anastomoses, infections or bleeding), including the possibility of death.

Due to the severity of the procedure itself and the risk of serious complications, the final assessment of the benefit is often influenced by the long duration of the patient's stay.

In the original settlement product of the National Health Fund, JGP G31 - Complex pancreatic procedures - the number of days of stay financed by the group was 54 . This meant that it was only starting with the 55th day of hospitalization that additional financing had to be covered by the payer.

In the course of work on the tariff, an attempt was also made to determine the new number of days financed by the group tariff. For procedures related to tail and pancreatic body procedures it was calculated according to the formula:

$$
Q 3+1,5 *(Q 3-Q 1)
$$

where:

Q1 denotes the first quartile;

Q3 denotes the third quartile.

The number of 27 days was thus obtained.

For the remaining procedures in group G31 (pancreatic head), as patients are in the group with a higher incidence of severe complications, reaching $50 \%$, the number of days of stay financed by the group was determined using a formula:

$$
Q 3+0,5 *(Q 3-Q 1)
$$

The number obtained was 34 days.

This means that in the case of splitting the G31 group into two, the number of days financed by the group's tariff should be 27 for the tail and pancreas body benefits and 34 for the other procedures.

In the analysis of foreign tariffs, apart from the valuation of benefits, special attention was paid to this parameter and information about the upper cut-off limit for hospitalizations similar or identical to G31 was searched. As a result, it was found that the groups varied depending on the complexity of the case, and therefore had different hospitalization times; the times calculated in the process of setting the benefit tariffs were similar to those used in foreign patient group systems. The following is the information from the tariff report for complex pancreatic treatments (Report WT.541.1.2017, completion date 30.11.2017).

\section{Australia}

Benefits provided as part of hospitalisation are accounted for under the financing system based on DRG groups - in this country called DRG v8.0 groups. Each group is assigned an appropriate weight, which should be multiplied by the valuation of the weight - the current value of one point is 4,910 AUD. The Australian system is based on: ICD-10, ACHI (Australian Classification of Health Interventions) and ACS (Australian Coding Standard) (ACCD 2016). Calculators were used in the development of this statement: NWAU calculator for acute activity 2016-2017 (Table IV).

The limitation of the following analysis is the lack of publicly available information on medical procedures performed within particular DRG groups.

\begin{tabular}{|l|c|c|c|c|}
\hline \multicolumn{1}{|c|}{ Group name } & $\begin{array}{c}\text { Group } \\
\text { code }\end{array}$ & $\begin{array}{c}\text { Upper limit } \\
\text { cut-off (days) }\end{array}$ & $\begin{array}{c}\text { Tariff } \\
\text { (AUD) }\end{array}$ & $\begin{array}{c}\text { Tariff } \\
\text { (PLN) }\end{array}$ \\
\hline $\begin{array}{l}\text { Treatment of pancreas, } \\
\text { liver, intestines, } \\
\text { high complexity }\end{array}$ & H01A & 72 & 56,587 & 153,424 \\
\hline $\begin{array}{l}\text { Treatment of pancreas, } \\
\text { liver, intestines, } \\
\text { medium complexity }\end{array}$ & H01B & 27 & 25,930 & 70,304 \\
\hline $\begin{array}{l}\text { Treatment of pancreas, } \\
\text { liver, intestines, } \\
\text { small complexity }\end{array}$ & H01C & 10 & 9,583 & 25,982 \\
\hline
\end{tabular}

Table IV. Australia - tariffs of groups equivalent or similar to JGP G31

Source: Report on the determination of the benefit tariff no. WT.541.1.2017. 


\section{The Czech Republic}

Contracts with service providers are the result of negotiations between representatives of service providers, insurance companies, hospital associations, scientific organisations and patient associations. A provider can enter into a contract with more than one insurer or even all health insurance companies. Health care costs are paid directly by the health insurance company.

Hospital services provided within the framework of hospitalisation are accounted for under the financing system based on the modified IR-DRG, taking into account the existing complications and coexisting diseases (Table V).

\begin{tabular}{|l|c|c|c|c|}
\hline \multicolumn{1}{|c|}{ Group name } & $\begin{array}{c}\text { Group } \\
\text { code }\end{array}$ & $\begin{array}{c}\text { Upper limit } \\
\text { cut-off (days) }\end{array}$ & $\begin{array}{c}\text { Tariff } \\
\text { (Kč) }\end{array}$ & $\begin{array}{c}\text { Tariff } \\
\text { (PLN) }\end{array}$ \\
\hline $\begin{array}{l}\text { Pancreas, liver and vas- } \\
\text { cular procedures without } \\
\text { complications }\end{array}$ & 07011 & 36 & 139,545 & 23,053 \\
\hline $\begin{array}{l}\text { Pancreas, liver and vas- } \\
\text { cular procedures with } \\
\text { complications }\end{array}$ & 07012 & 45 & 179,956 & 29,729 \\
\hline $\begin{array}{l}\text { Pancreas, liver and vas- } \\
\text { cular procedures with } \\
\text { severe complications }\end{array}$ & 07013 & 66 & 286,149 & 47,272 \\
\hline $\begin{array}{l}\text { Other treatments for } \\
\text { hepato-biliary and } \\
\text { pancreatic diseases } \\
\text { and disorders without } \\
\text { complications }\end{array}$ & 07051 & 24 & 53,747 & 8,879 \\
\hline $\begin{array}{l}\text { Other treatments for } \\
\text { hepato-biliary and } \\
\text { pancreatic diseases } \\
\text { and disorders with } \\
\text { complications }\end{array}$ & 07052 & 59 & 69,748 & 11,522 \\
\hline $\begin{array}{l}\text { Other treatments for } \\
\text { hepato-biliary and } \\
\text { pancreatic diseases and } \\
\text { disorders with severe } \\
\text { complications }\end{array}$ & 07053 & 54 & 20,941 \\
\hline
\end{tabular}

Table V. Czech Republic - tariffs of groups equivalent or similar to JGP G31

Source: Report on the determination of the benefit tariff no. WT.541.1.2017

\section{Lithuania}

The Lithuanian DRG system is based on Australian solutions. No information was found as to whether the tariffs found included all the costs of providing services. Cost of identified groups equivalent or similar to JGP G31: 4,337 - 19,180 PLN (Table VI).

\begin{tabular}{|l|c|c|c|}
\hline \multicolumn{1}{|c|}{ Group name } & $\begin{array}{c}\text { Group } \\
\text { code }\end{array}$ & $\begin{array}{c}\text { Tariff } \\
\text { (EUR) }\end{array}$ & $\begin{array}{c}\text { Tariff } \\
\text { (PLN) }\end{array}$ \\
\hline $\begin{array}{l}\text { Pancreatic, hepatic and vascular proce- } \\
\text { dures - when there are life-threatening } \\
\text { complications or coexisting diseases }\end{array}$ & H01A & 4,555 & 19,180 \\
\hline $\begin{array}{l}\text { Pancreatic, hepatic and vascular proce- } \\
\text { dures - where there are no life-threaten- } \\
\text { ing complications or coexisting diseases }\end{array}$ & H01B & 2,025 & 8,527 \\
\hline $\begin{array}{l}\text { Other hepatic, biliary and pancreatic } \\
\text { procedures in the operating room - } \\
\text { when there are life-threatening compli- } \\
\text { cations or coexisting diseases }\end{array}$ & H06A & 3,065 & 12,906 \\
\hline $\begin{array}{l}\text { Other hepatic, biliary and pancreatic } \\
\text { procedures in the operating room - } \\
\text { in the absence of life-threatening com- } \\
\text { plications or coexisting diseases }\end{array}$ & H06B & 1,030 & 4,337 \\
\hline
\end{tabular}

Table VI. Lithuania - tariffs of groups equivalent or similar to JGP G31

Source: Report on the determination of the benefit tariff no. WT.541.1.2017.

\section{Germany}

Benefits provided in hospitals are settled in the G-DRG system, which is based on the Australian system. Each group is assigned a weight in points, which should be multiplied by the cost of the point. In 2017, the average point value was $3,376.11 €$. The benefit groups in the German DRG system take into account the complexity of treatments, the presence of complications and coexisting diseases. The tariffs presented relate to the base groups. H01 groups include, in addition to procedures with the JGPG31, treatments with the JGP G01 Extensive liver treatments (worth 15,196 points) (Table VII).

Additional payments are added to the value of hospitalization.

\begin{tabular}{|l|c|c|c|c|}
\hline \multicolumn{1}{|c|}{ Group name } & $\begin{array}{c}\text { Group } \\
\text { code }\end{array}$ & $\begin{array}{c}\text { Upper limit } \\
\text { cut-off (days) }\end{array}$ & $\begin{array}{c}\text { Tariff } \\
\text { (EUR) }\end{array}$ & $\begin{array}{c}\text { Tariff } \\
\text { (PLN) }\end{array}$ \\
\hline $\begin{array}{l}\text { Pancreatic, liver and } \\
\text { extensive vascular pro- } \\
\text { cedures or radiotherapy, } \\
\text { with comprehensive } \\
\text { surgical treatment or } \\
\text { intensive comprehensive } \\
\text { care }>392 / 368 / \text {-point }\end{array}$ & H01A & 37 & 20,710 & 87,205 \\
\hline
\end{tabular}




\begin{tabular}{|c|c|c|c|c|}
\hline Group name & $\begin{array}{c}\text { Group } \\
\text { code }\end{array}$ & $\begin{array}{l}\text { Upper limit } \\
\text { cut-off (days) }\end{array}$ & $\begin{array}{l}\text { Tariff } \\
\text { (EUR) }\end{array}$ & $\begin{array}{l}\text { Tariff } \\
\text { (PLN) }\end{array}$ \\
\hline $\begin{array}{l}\text { Pancreatic, liver and } \\
\text { extensive vascular pro- } \\
\text { cedures or radiotherapy, } \\
\text { without comprehen- } \\
\text { sive surgical treat- } \\
\text { ment or intensive care } \\
>392 / 368 / \text {-point }\end{array}$ & H01B & 34 & 16,010 & 67,415 \\
\hline $\begin{array}{l}\text { Pancreatic, liver and } \\
\text { non-extensive vascular } \\
\text { procedures, without radio- } \\
\text { therapy, with particularly } \\
\text { severe complications, } \\
\text { with specific surgery on } \\
\text { the liver, pancreas and } \\
\text { bile ducts }\end{array}$ & H09A & 37 & 14,745 & 62088 \\
\hline $\begin{array}{l}\text { Pancreatic, liver proce- } \\
\text { dures and non-extensive } \\
\text { vascular procedures, } \\
\text { without radiotherapy, with } \\
\text { or without particularly } \\
\text { severe complications, } \\
\text { with specific surgery on } \\
\text { the pancreas or in malig- } \\
\text { nant tumours }\end{array}$ & H09B & 20 & 9,502 & 40,011 \\
\hline $\begin{array}{l}\text { Pancreatic, liver proce- } \\
\text { dures and non-extensive } \\
\text { vascular procedures } \\
\text { without radiotherapy, } \\
\text { without particularly } \\
\text { severe complications, } \\
\text { without specific treatment } \\
\text { of the pancreas except for } \\
\text { malignant tumours }\end{array}$ & $\mathrm{H} 09 \mathrm{C}$ & 17 & 6,862 & 28,896 \\
\hline
\end{tabular}

Table VII. Germany - tariffs of groups equivalent or similar to JGP G31

Source: Report on the determination of the benefit tariff no. WT.541.1.2017.

\section{Slovakia}

In Slovakia, hospitalisation services are accounted for under the funding system based on DRG groups. Each group is assigned a weight, which is multiplied by the valuation of the weight with a point value depending on the type of hospital. The current value of one point is:

- national reference rate: $1,244 €$;

- general hospital 1: $835 €$

- general hospital 2: $899 €$;

- general hospital 3: 1,178 €;

- general hospital 4: 1,411 €;

- specialist institutes - cardiovascular disease institutes: $2,419 €$;

- specialist institutes - oncological institutes: $1,818 €$.

In 2011, the German DRG system was introduced in Slovakia. Hospitalisations related to the treatment of spinal diseases are accounted for in identical groups as in the German system (Table VIII). For the purpose of the study, the value of the point for oncological institutes was assumed to be $1,818 €$.

\begin{tabular}{|c|c|c|c|c|}
\hline Group name & $\begin{array}{l}\text { Group } \\
\text { code }\end{array}$ & $\begin{array}{c}\text { Upper limit } \\
\text { cut-off (days) }\end{array}$ & \begin{tabular}{|c|} 
Tariff \\
(EUR)
\end{tabular} & $\begin{array}{l}\text { Tariff } \\
\text { (PLN) }\end{array}$ \\
\hline $\begin{array}{l}\text { Pancreatic, liver and } \\
\text { extensive vascular pro- } \\
\text { cedures or radiotherapy, } \\
\text { with comprehensive surgi- } \\
\text { cal treatment }\end{array}$ & $\mathrm{H} 01 \mathrm{~A}$ & 37 & 12,398 & 52,205 \\
\hline $\begin{array}{l}\text { Pancreatic, liver and } \\
\text { extensive vascular } \\
\text { procedures with treatment } \\
\text { or radiotherapy, without } \\
\text { comprehensive surgical } \\
\text { treatment }\end{array}$ & $\mathrm{H} 01 \mathrm{~B}$ & 34 & 9,373 & 39,468 \\
\hline $\begin{array}{l}\text { Pancreas, liver and } \\
\text { non-extensive vascular } \\
\text { procedures without radio- } \\
\text { therapy, with particularly } \\
\text { severe complications }\end{array}$ & H09A & 37 & 8,012 & 33,737 \\
\hline $\begin{array}{l}\text { Pancreatic, liver and } \\
\text { non-extensive vascu- } \\
\text { lar procedures without } \\
\text { radiotherapy, in malignant } \\
\text { tumours with specific pan- } \\
\text { creatic procedures }\end{array}$ & H09B & 20 & 5,405 & 22,758 \\
\hline $\begin{array}{l}\text { Pancreas, liver and } \\
\text { non-extensive vascu- } \\
\text { lar procedures without } \\
\text { radiotherapy, without } \\
\text { specific pancreatic treat- } \\
\text { ment except for malignant } \\
\text { tumours }\end{array}$ & $\mathrm{H} 09 \mathrm{C}$ & 17 & 3,585 & 15,096 \\
\hline
\end{tabular}

Table VIII. Slovakia - tariffs of groups equivalent or similar to JGP G31

Source: Report on the establishment of the benefit tariff no. WT.541.1.2017.

\section{Hip endoprosthesis - comprehensive care}

Endoprosthesis of the hip joint consists in removing the damaged hip joint and replacing it with an artificial one, i.e. a prosthesis. An endoprosthesis consists of an element replacing the closer part of the femur (i.e. a mandrel made of metal alloy and a head made of metal alloy or ceramics). Implants used in hip endoprosthesis are made of biocompatible materials, i.e. materials accepted by the body and created in a way that provides the greatest resistance to corrosion, destruction and wear. The socket or mandrel can be fixed directly to the bone or with special cement. The choice of the type of endoprosthesis and surgical technique depends on the severity of degenerative changes, the age of the patient and their state of health. Currently there are many different types of hip endoprosthesis procedures. Endoprosthetic procedures can be divided into primary and revision endoprosthesis, depending on the nature of the procedure: total, partial and hip resurfacing endoprosthesis; depending on the type of prosthesis used: cement, cement-free, hybrid; or finally, depending on the type of material from which the prosthesis/articulation is made. 
The final result of treatment with total endoprosthesis is determined not only by professional performance of the procedure itself. Equally important is the physical and mental preparation of the patient for the planned operation and proper pre- and postoperative care. At the same time it is important to convince the patient of the need for treatment and rehabilitation. It is important for the patient to improve their efficiency in performing basic everyday activities, better mood and quality of life.

When analysing the services related to the provision of comprehensive care to patients with hip joint endoprosthesis, special attention was paid to the share of costs of implants used during the endoprosthetic procedure and the amount of reimbursement in individual countries. Moreover, solutions in the field of endoprosthesis were sought: partial, primary and revision endoprosthesis.

The following is the information from the tariff report for hip joint endoprosthesis - comprehensive care (Report WT.541.26.2016, completion date 20.07.2016).

The classification of homogeneous groups of patients and payment for hip surgery varies greatly between countries across Europe. For example, the number of DRG groups that individually account for at least $1 \%$ of hip replacement patients varies from two in Estonia and Sweden to ten in France and even 14 in England. Similarly, the number and characteristics of patients and the type of treatment that are taken into account by each DRG classification. For example, all DRG systems distinguish between total joint endoprosthesis and revision endoprosthesis, but only 4 systems have DRG groups dedicated to partial endoprosthesis. Furthermore, main and secondary diagnoses are used to classify patients in England, France, Germany, Spain and Ireland. The grouping of hip endoprosthesis based on age and length of stay (LOS) is performed only in France and Germany.

Caution should be exercised when comparing DRG systems due to differences in data/hospital samples. Due to the relatively poor capability of some DRG models to explain the differences in costs of these systems, it may be beneficial to include patient characteristics in the definition of relevant groups. For example, although all countries distinguish between primary and revision surgery, only four countries have groups for partial surgery. The results of the analysis suggest that including this variable in the classification may improve accountability. The mechanism for accounting for co-existing diagnoses varies considerably from country to country. However, some countries, such as the NordDRG countries and Austria, do not take into account secondary recognition, and yet do not have a worse resource use. The analysis shows that coexisting diseases play a minor role in the variability of resource use, such as the Charlson Index (coexisting diseases) and side effects have no significant impact on hospital costs. It is also worth noting that DRG systems in countries with a higher number of DRGs do not necessarily work better than those with fewer groups. This suggests that the number of DRG groups is not a good predictor of the capacity of DRG systems to explain differences in resource consumption.

\section{Costs of endoprosthesis in individual countries}

Implants (on average 34\% of total costs) and hospital costs (on average $20.9 \%$ of total costs) are considered to be the main cost factors in hip endoprosthesis. Large differences in costs and reimbursement between Poland, Hungary and other EU Member States were noted. The lowest reimbursement from the payer takes place in Poland, followed by Hungary. The highest reimbursement significantly exceeding the costs related to endoprosthesies is observed in Denmark and England. The real cost of the procedure is difficult to present in different countries due to different health care systems and financing methods. In some systems the cost of the service provider may be included in the real cost of the procedure.

The total price of hip endoprosthesis (including implant and rehabilitation) varies between countries. In Lithuania the price can range from $€ 3,800$ to $€ 7,900$, in the Czech Republic from $€ 7,100$ to $€ 7,400$, in Estonia from $€ 5,200$ to $€ 5,600$, in France from $€ 11,000$ to $€ 11,500$, in Germany from $€ 10,500$ to $€ 10800$, in Ireland from $€ 15,700$ to $€ 16,000$, in Poland from $€ 4,500$ to $€ 5,000$, in the UK from $€ 11,800$ to $€ 12,300$, and in Norway from $€ 10,000$ to $€ 10,500$.

\section{Official tariffs per country}

The median of official prices from the analysed countries (England, Scotland, Australia, New Zealand, Lithuania, Slovenia, Slovakia, Serbia and Hungary) for particular hip endoprosthesis services is respectively PLN 24,573 for partial endoprosthesis in the H02 group and PLN 23,634 for total cement endoprosthesis in the H04 group, total cement-free endoprosthesis in the group H05 - PLN 33,569, endoprosthesis with the use of metaphyseal mandrel and hip resurfacing in the group PLN H06 - 21,530, during surgery with the use of bone grafts in the group PLN H06 - 37,487, during partial revision surgery - PLN 22,10 and total surgery - PLN 22,694.

\section{Guaranteed benefits covering the treatment of nervous system diseases by means of implantable electrical stimulation devices financed by JGP A03 and A04}

The groups A03 Injection of a deep brain stimulator/vagus nerve stimulator and A04 Injection/replacement of a spinal cord stimulator or replacement of a deep brain stimulator include some diseases of the nervous system not undergoing pharmacological treatment - motor disorders and pain syndromes. Among the diagnoses occurring in the characteristics of both groups dominate Parkinson's disease, dystonia, epilepsy and neuralgia with muscle atrophy. A significant cost in these groups is the value of the medical device - the neurostimulator. Depending on its type, power supply, rechargeability, its value may vary considerably. In the case of analgesic stimulation of the spinal cord, in addition to the device itself, the cost of the service is also affected by the need to perform the so-called test stimulation. 
The programming of the stimulators and their control are also important. Therefore, the foreign tariffs for the services in question were analysed: the design of the service, the services accompanying neurostimulation and the ways of including high cost medical devices in the design of the service. Information on the costs of devices and methods of their settlement was sought.

The following conclusions were drawn from the analyses carried out:

- some countries have financed neurostimulation devices separately. In the case of Germany, the minimum costs were strictly defined, with the possibility of additional financing by the health insurance fund under separate agreements;

- the foreign tariffs included a test implantation, which was not provided for in the JGP catalogue; in some countries, advice on regulation and programming of the device was financed.

The results of the above analyses have been taken into account in the tariff proposals and recommendations for provision.

Below is a selection of information from the tariff report for guaranteed benefits covering the treatment of nervous system diseases with the use of implantable electrical stimulation devices, financed under the JGP A03 and A04 (Report WT.541.28.2016, completion date 26.10.2016).

\section{Germany}

The cost of groups equivalent or similar to the JGP A03 and A04:

- deep brain stimulation (the cost of the implant is included in the cost of the group), from PLN 72,692 to 140,213 ;

- vagus nerve stimulation: procedure PLN 24,136 and the cost of the implant, which is added depending on the type of implant and method of implantation (fixed price set in the DRG catalogue, 2 items), from PLN 39,314 - 45,086;

- spinal cord stimulation: procedure PLN 12,267 and the cost of the implant, which is added depending on the implant type and method of implantation (fixed price established in DRG catalogue, 4 items), from PLN 27,918 to 49,748 .

In the case of more cost-intensive products an additional refund is possible (Tables IX-XI).

\begin{tabular}{|l|c|c|c|}
\hline \multicolumn{1}{|c|}{ Group name } & $\begin{array}{c}\text { Group } \\
\text { code }\end{array}$ & $\begin{array}{c}\text { Tariff } \\
\text { (EUR) }\end{array}$ & $\begin{array}{c}\text { Tariff } \\
\text { (PLN) }\end{array}$ \\
\hline $\begin{array}{l}\text { Treatment of peripheral nerves, cranial } \\
\text { nerves and other parts of the nervous } \\
\text { system or treatments for cerebral palsy, } \\
\text { muscular dystrophy or neuropathy, or } \\
\text { diagnosis of or treatments for cerebral } \\
\text { palsy, muscular dystrophy or neu- } \\
\text { ropathy, or complicated diagnosis, or } \\
\text { implantation of an event recorder, with } \\
\text { comprehensive intervention }\end{array}$ & B17B & 5,610 & 24,136 \\
\hline
\end{tabular}

\begin{tabular}{|l|c|c|c|}
\hline \multicolumn{1}{|c|}{ Group name } & $\begin{array}{c}\text { Group } \\
\text { code }\end{array}$ & $\begin{array}{c}\text { Tariff } \\
\text { (EUR) }\end{array}$ & $\begin{array}{c}\text { Tariff } \\
\text { (PLN) }\end{array}$ \\
\hline $\begin{array}{l}\text { Injection of a neurostimulator for brain } \\
\text { stimulation, multi-electrode system, } \\
\text { with electrode implantation }\end{array}$ & B21A & 32,593 & 140,213 \\
\hline $\begin{array}{l}\text { Injection of a neurostimulator for brain } \\
\text { stimulation, multi-electrode system, } \\
\text { without electrode implantation }\end{array}$ & $\mathrm{B} 21 \mathrm{~B}$ & 16,898 & 72,692 \\
\hline $\begin{array}{l}\text { Other uncomplicated spinal treatments, } \\
\text { more than one day's stay }\end{array}$ & $\mathrm{I10G}$ & 2,852 & 12,267 \\
\hline
\end{tabular}

Table IX. Germany - tariffs equivalent or similar to the JGP A03 and A04 tariffs

Source: Report on the establishment of the benefit tariff no WT.541.28.2016.

\begin{tabular}{|c|c|c|c|}
\hline $\begin{array}{l}\text { Subsidy } \\
\text { code }\end{array}$ & Description & $\begin{array}{c}\text { Cost } \\
(\text { EUR })\end{array}$ & $\begin{array}{c}\text { Cost } \\
(\text { PLN) }\end{array}$ \\
\hline ZE138 & $\begin{array}{l}\text { Neurostimulators for spinal cord } \\
\text { stimulation or for peripheral } \\
\text { nerve stimulation, single-chan- } \\
\text { nel, chargeable, with electrode } \\
\text { implantation }\end{array}$ & $7,487.43$ & 32,210 \\
\hline ZE139 & $\begin{array}{l}\text { Neurostimulators for spinal cord } \\
\text { stimulation or for peripheral } \\
\text { nerve stimulation, single- } \\
\text { channel, chargeable, without } \\
\text { electrode implantation }\end{array}$ & $6,489.63$ & 27,918 \\
\hline ZE140 & $\begin{array}{l}\text { Neurostimulators for spinal cord } \\
\text { stimulation or for peripheral } \\
\text { nerve stimulation, multichan- } \\
\text { nel, not charged, with electrode } \\
\text { implantation }\end{array}$ & $11,564.22$ & 49,748 \\
\hline ZE141 & $\begin{array}{l}\text { Neurostimulators for spinal cord } \\
\text { stimulation or for peripheral } \\
\text { nerve stimulation, multichannel, } \\
\text { non-charged, without electrode } \\
\text { implantation }\end{array}$ & $10,321.86$ & 44,404 \\
\hline ZE158 & $\begin{array}{l}\text { Vagus nerve stimulation system, } \\
\text { with electrode implantation }\end{array}$ & $10,485.29$ & 45,107 \\
\hline ZE159 & $\begin{array}{l}\text { Vagus nerve stimulation system, } \\
\text { without electrode implantation }\end{array}$ & $9,142.81$ & 39,331 \\
\hline
\end{tabular}

Table X. Germany - Cost of equipment indicated in the catalogue of additional charges

Source: Report on the establishment of the benefit tariff No WT.541.28.2016.

\begin{tabular}{|c|l|}
\hline $\begin{array}{c}\text { Subsidy } \\
\text { code }\end{array}$ & \multicolumn{1}{c|}{ Description } \\
\hline ZE2016-61 & $\begin{array}{l}\text { Neurostimulators to stimulate the brain or spinal } \\
\text { cord or to stimulate peripheral nerves, multichannel, } \\
\text { chargeable }\end{array}$ \\
\hline
\end{tabular}

Table XI. Germany - Equipment for which additional charges may be levied

Source: Report on the establishment of the benefit tariff no WT.541.28.2016. 


\section{Slovakia}

In Slovakia, the base rate for a point in hospitalisation depends on the type of hospital and is as follows:

- for general hospitals: 1,002.64 €;

- for university hospitals (including children): 1,552.74 euro;

- for type 1 specialist hospitals (cardiology): 3,928.45 euro;

- for type 2 specialist hospitals (oncology): 2,944.89 euro;

- for type 3 specialist hospitals (other): 1,927.19 euro.

The cost of groups similar to JGP A03 and A04 are shown in the tables below (Table XII-XIV). Minimum tariffs calculated for point values for general hospitals, maximum - for type 3 specialist hospital. No groups dedicated to neurostimulation were found. This may mean that the cost of products is not included in the tariff.

\begin{tabular}{|l|l|l|l|}
\hline \multicolumn{1}{|c|}{ Group name } & $\begin{array}{c}\text { Group } \\
\text { code }\end{array}$ & $\begin{array}{c}\text { Tariff } \\
\text { min.-max. } \\
\text { (EUR) }\end{array}$ & $\begin{array}{c}\text { Tariff } \\
\text { min.-max. } \\
\text { (PLN) }\end{array}$ \\
\hline Treatment groups & \multicolumn{2}{|l|}{} \\
\hline $\begin{array}{l}\text { Extensive surgery not related } \\
\text { to the main diagnosis, no } \\
\text { concomitant complications, } \\
\text { no radiotherapy, no endo- } \\
\text { vascular aortic procedures, } \\
\text { with comprehensive surgical } \\
\text { treatment }\end{array}$ & $901 \mathrm{~B}$ & $4,393-8,444$ & $18,898-36,325$ \\
\hline $\begin{array}{l}\text { Craniotomy or major spinal } \\
\text { surgery with complex sur- } \\
\text { gery, age over 15, with intra- } \\
\text { operative neurophysiological } \\
\text { monitoring or complex } \\
\text { diagnostics }\end{array}$ & B20B & $3,677-7,069$ & $15,818-30,410$ \\
\hline $\begin{array}{l}\text { Other spinal treatments with- } \\
\text { out severe complications and } \\
\text { concomitant diseases, with } \\
\text { a complex treatment or Halo } \\
\text { traction, without breaking } \\
\text { the vertebrae except for } \\
\text { tetraplegia }\end{array}$ & I10D & $1,746-3,357$ & $7,511-14,441$ \\
\hline
\end{tabular}

Table XII. Slovakia - tariffs for groups similar in characteristics to JGP A03 and A04, for groups where neurostimulator implantation procedures are performed

Source: Report on the establishment of the benefit tariff no WT.541.28.2016.

\begin{tabular}{|l|l|l|l|}
\hline \multicolumn{1}{|c|}{ Group name } & $\begin{array}{c}\text { Group } \\
\text { code }\end{array}$ & $\begin{array}{c}\text { Tariff } \\
\text { min.-max. } \\
\text { (EUR) }\end{array}$ & $\begin{array}{c}\text { Tariff } \\
\text { min.-max. } \\
\text { (PLN) }\end{array}$ \\
\hline Non-surgical group & . & \\
\hline $\begin{array}{l}\text { Seizures, one day's stay, or } \\
\text { without complex diagnosis } \\
\text { and treatment, without severe } \\
\text { complications and concomitant } \\
\text { diseases, without EEG, age }>5 \\
\text { years, without complex diagnosis }\end{array}$ & B76G & $679-1304$ & $2921-5610$ \\
\hline
\end{tabular}

Table XIII. Slovakia - tariff for the group in which the neurostimulator programming can be accounted for

Source: Report on the establishment of the benefit tariff no WT.541.28.2016.

\begin{tabular}{|l|c|c|c|}
\hline \multicolumn{1}{|c|}{ Group name } & $\begin{array}{c}\text { Group } \\
\text { code }\end{array}$ & $\begin{array}{c}\text { Tariff, } \\
\text { min.-max. } \\
\text { (EUR) }\end{array}$ & $\begin{array}{c}\text { Tariff, } \\
\text { min.-max. } \\
\text { (PLN) }\end{array}$ \\
\hline $\begin{array}{l}\text { Control of the neurostimulation } \\
\text { device }\end{array}$ & - & $4-6$ & $17-26$ \\
\hline
\end{tabular}

Table XIV. Slovakia - outpatient tariff

Source: Report on the establishment of the benefit tariff no WT.541.28.2016.

\section{Slovenia}

The cost of groups equivalent or similar to JGP A03 and A04 (Table XV):

- for group A03, deep brain stimulation: PLN 128,709;

- for group A04,(spinal cord stimulation) and includes: - a trial core pacemaker implantation: PLN 7,442;

- re-implantation or generator implantation: PLN 6,840;

- cost of products (depending on the type of stimulator, 4 types): from PLN 32,002 to 74,259.

\begin{tabular}{|l|c|c|c|}
\hline \multicolumn{1}{|c|}{ Name of benefit } & $\begin{array}{c}\text { Group } \\
\text { code }\end{array}$ & $\begin{array}{c}\text { Tariff } \\
\text { (EUR) }\end{array}$ & $\begin{array}{c}\text { Tariff } \\
\text { (PLN) }\end{array}$ \\
\hline Stimulation of deep brain structures & - & 29,919 & 128,709 \\
\hline $\begin{array}{l}\text { Qualification of patients for } \\
\text { neurostimulation }\end{array}$ & - & 513 & 2,207 \\
\hline $\begin{array}{l}\text { Implantation material with one test } \\
\text { electrode }\end{array}$ & - & 7,439 & 32,002 \\
\hline $\begin{array}{l}\text { Implantation material with two test } \\
\text { electrodes }\end{array}$ & - & 12,153 & 52,281 \\
\hline $\begin{array}{l}\text { Subcutaneous stimulator and patient } \\
\text { rehabilitation }\end{array}$ & - & 17,262 & 74,259 \\
\hline $\begin{array}{l}\text { Material for reimplantation with one } \\
\text { electrode and permanent subcutaneous } \\
\text { stimulator and patient rehabilitation }\end{array}$ & - & 14,322 & 61,612 \\
\hline Neurosurgical electrode implantation & - & 1,730 & 7,442 \\
\hline $\begin{array}{l}\text { Neurosurgical implantation of a per- } \\
\text { manent subcutaneous pacemaker }\end{array}$ & - & 1,590 & 6,840 \\
\hline $\begin{array}{l}\text { Neurosurgical reimplantation of } \\
\text { the electrode and permanent subcuta- } \\
\text { neous stimulator }\end{array}$ & - & 1,590 & 6,840 \\
\hline
\end{tabular}

Table XV. Slovenia - tariffs equivalent or similar to the JGP A03 and A04 tariffs

Source: Report on the establishment of the benefit tariff no WT.541.28.2016. 


\section{Guaranteed henefits including hospitalizations for chemo- and radiotherapy}

During the work on the tariff for the stay services provided as part of hospitalization for chemo- and radiotherapy, information was sought on the method of their settlement and the methodology of tariff construction. The result of this analysis is an example of how difficult it sometimes seems to find information about a product that is seemingly simple to determine, which is a person-day stay of a patient with cancer undergoing chemo- or radiotherapy. Only one premise was found that could indicate the cost associated with such hospitalization.

This is most likely due to a different design of oncology services in the analysed countries, which differs from the Polish system. In the example given from the German hospital services catalogue, an indication of the value of a person-day of hospitalization may be the weight of the benefit above the upper cut-off limit, which is practically identical (from 0.091 to 0.096 per day of stay), despite marked differences in the weight of the indicated groups (from 0.731 to 1.756). Attention should also be paid to the attempt to compare the amount of benefit taking into account the CPL index.

As the work on the tariff has not yet been completed, further research will be carried out which could enable the construction of the benefits analysed to be compared.

Below is a selection of information from the tariff report for guaranteed services including hospitalizations for chemo- and radiotherapy (Report WT.521.10.2017, ongoing).

\section{Germany}

Benefits provided in hospitals are settled in the G-DRG system, which is based on the Australian system. Each group is assigned a weight in points, which should be multiplied by the cost of the point. In 2019, the base rate per point in the German system is $€ 3544.97$. The indicated benefit groups in the German DRG system take into account the complexity of treatment, the age of the patient and the length of stay and the presence of complications and concomitant diseases. The tariffs presented are based on base groups.

While the value of the base product most likely takes into account virtually the entire treatment process, the value factor for each day above the upper cut-off may indicate an approximate value for one day of hospitalisation. In these cases it ranges from 0.091 to 0.096 , i.e. from about $€ 323$ (PLN 1,382) to about $€ 343$ (PLN 1,468) respectively. Including CPL, the man-day value is estimated at 739 PLN and 785 PLN (Table XVI).

\section{Summary}

Medical services, as a product subject to market mechanisms - buying and selling - should be subject to valuation that would determine their value. The value of a patient's treatment process includes various facilities and activities, including medical procedures. Determining their costs is one of the most important conditions for the valuation of health services at the central level and is an essential factor of an effective health care financing system.

In-patient care financing systems in most European countries, including Poland, are based on the Diagnosis Related Group (DRG) system. DRG systems aim to increase the transparency of services provided in hospitals and to increase efficiency in the use of available resources and, consequently, the quality of medical care. The main goal of DRG systems is to classify patients into specific groups that are homogenous taking into account their clinical aspect and the use of resources.

The process of valuation of health services will vary from country to country due to its diversity at the level of financing methods, the way patients are classified, as well as the type of medical technologies used.

In order to compare the way and level of financing of the services being valued with their counterparts in other countries, the AOTMiT analyzes and compares

\begin{tabular}{|c|c|c|c|c|c|c|c|c|c|}
\hline \multirow{2}{*}{ Code } & \multirow{2}{*}{ Name } & \multirow{2}{*}{ Weight } & \multirow{2}{*}{$\begin{array}{c}\text { Average } \\
\text { lenght of stay }\end{array}$} & \multicolumn{2}{|c|}{$\begin{array}{c}\text { Lower limit } \\
\text { cut-off (days) }\end{array}$} & \multicolumn{2}{|c|}{$\begin{array}{c}\text { Upper limit } \\
\text { cut-off (days) }\end{array}$} & \multirow{2}{*}{$\begin{array}{l}\text { Tariff } \\
\text { DE }[\epsilon]\end{array}$} & \multirow{2}{*}{$\begin{array}{c}\text { Tariff PL } \\
{[\text { PLN] }}\end{array}$} \\
\hline & & & & day & $\begin{array}{c}\text { weight/ } \\
\text { day }\end{array}$ & day & $\begin{array}{l}\text { weight/ } \\
\text { day }\end{array}$ & & \\
\hline M60A & $\begin{array}{l}\text { Malignant tumours of male genital organs, more than } \\
\text { a day, age }<11 \text { years or particularly severe complica- } \\
\text { tions and concomitant diseases }\end{array}$ & 1,756 & 12,3 & 3 & 0,419 & 26 & 0,096 & 6225 & 26636 \\
\hline M60B & $\begin{array}{l}\text { Malignant tumours of male genital organs, one day } \\
\text { stay, age }>10 \text { years, without particularly severe } \\
\text { complications and concomitant diseases, with highly or } \\
\text { moderately compiled chemotherapy }\end{array}$ & 0,760 & 5,5 & 1 & 0,373 & 10 & 0,095 & 2694 & 11527 \\
\hline M60C & $\begin{array}{l}\text { Malignant tumours of male genital organs, one day } \\
\text { stay, age }>10 \text { years, no particularly severe complica- } \\
\text { tions and concomitant diseases, no highly or moder- } \\
\text { ately compiled chemotherapy }\end{array}$ & 0,731 & 5,0 & 1 & 0,380 & 13 & 0,091 & 2591 & 11086 \\
\hline
\end{tabular}

Table XVI. Examples of groups from the German DRG catalogue with the possibility of accounting for chemo- or radiotherapy Source: Report on the establishment of the benefit tariff no WT.521.10.2017. 
information about the valuation of services in European countries, especially those of GDP per capita similar to Poland. The use of benefit valuations in other countries requires the collection of information about the process of data collection, data analysis and factors taken into account that affect the final value of the valuation. In addition, the method of classification of patient groups, methods of payment and the shape of benefits are examined.

The results of the conducted analyses have an impact on the design of the services and are often included in the design of tariffs and AOTMiT recommendations for the products being valued.

\section{References}

1. Kludacz-Alessandri M., Popytowe i kosztowe aspekty wyceny świadczeń zdrowotnych, w: Kludacz-Alessandri M., Model wyceny świadczeń zdrowotnych dla lecznictwa szpitalnego, Wolters Kluwer, Warszawa 2017: 17-57.

2. Ustawa $\mathrm{z}$ dnia 27 sierpnia 2004 roku o świadczeniach opieki zdrowotnej finansowanych ze środków publicznych (Dz.U. z 2019 roku poz.1373).

3. Tan Siok Swan et al., DRG systems in Europe: Variations in cost accounting systems among 12 countries, "European Journal of Public Health" 2014; 24 (6): 1023-1028.

4. Kobel C. et al., Systemy DRG i zbliżone systemy kwalifikacji pacjentów w Europie, w: Busse R. et al., Jednorodne grupy pacjentów w Europie. W stronę przejrzystości, efektywności i jakości w szpitalach, Narodowy Fundusz Zdrowia - Centrala, Warszawa 2013: 55-79.

5. https://www.3m.com/3M/en_US/health-information-systems-us/providers/grouping-and-classification/apr-drgs/ (accessed: 18.07.2019).

6. https://www.ihpa.gov.au/publications/development-australian-refined-diagnosis-related-groups-ar-drg-v90 (accessed: 18.07.2019).

7. https://app.reimbursement.info/drgs?years $=2019 \&$ mdcs $=24$ (accessed: 18.07.2019).
8. https://www.atih.sante.fr/methode-alternative-la-comparaison-des-couts-et-des-tarifs-campagne-tarifaire-2018 (accessed: 18.07.2019).

9. http://www.norddrg.net/norddrgmanual/NordDRG_2012 NC/index.htm (accessed: 18.07.2019).

10. https://improvement.nhs.uk/resources/national-tariff/ (accessed: 18.07.2019).

11. Zarządzenie nr 77/2019/DSOZ Prezesa Narodowego Funduszu Zdrowia z dnia 27 czerwca 2019 roku zmieniające zarządzenie w sprawie określenia warunków zawierania i realizacji umów w rodzaju leczenie szpitalne oraz leczenie szpitalne - świadczenia wysokospecjalistyczne.

12. https://www.sozialministerium.at/site/Gesundheit/Gesundheitssystem/Krankenanstalten/LKF_Modell_2019/ Kataloge_2019 (accessed: 18.07.2019).

13. https://www.hspm.org/countries/netherlands25062012/ livinghit.aspx? Section $=3.7 \% 20$ Payment $\% 20$ mechanisms\&Type=Section (accessed: 18.07.2019).

14. Czach K. et al., Polska: Jednorodne Grupy Pacjentów polskie doświadczenia z DRG, w: Busse R. et al., Jednorodne grupy pacjentów w Europie. W stronę przejrzystości, efektywności i jakości w szpitalach, Narodowy Fundusz Zdrowia - Centrala, Warszawa 2013: 389-408.

15. Kludacz-Alessandri M., Zasady rachunku kosztów i wyceny świadczeń zdrowotnych $w$ wybranych krajach europejskich - analiza porównawcza, w: Kludacz-Alessandri M., Model wyceny świadczeń zdrowotnych dla lecznictwa szpitalnego, Wolters Kluwer, Warszawa 2017: 142-177.

16. Agencja Oceny Technologii Medycznych i Taryfikacji, Metodyka taryfikacji świadczeń opieki zdrowotnej w AOTMiT, http://www.aotm.gov.pl/www/wp-content/uploads/taryfikacja/Metodyka_taryfikacji/Metodyka_taryfikacji_swiadczen_opieki_zdrowotnej_w_AOTMiT.pdf (accessed: 18.07. 2019).

17. Błaszczyński A., Stownik pojęć ekonomicznych (Glossary of Economic Terms), Szkoła Zarządzania Uniwersytetu Jagiellońskiego, Kraków 1995.

18. Błaszczyński A., Stownik ekonomiczny dla przedsiębiorcy w warunkach rynkowych, Znicz, Szczecin 1994. 